\title{
SEX, ROCKS, AND TAXIDERMY: A CONVERSATION WITH CHRIS OFFUTT
}

I first met Chris Offutt outside the fabled Foxhead bar on Iowa City's east side. What I had heard about Chris Offutt was that he graduated from the Workshop during the fabled Conroy days-when Frank Conroy ruled the Workshop with painstaking intensity and tough love-and that he wrote about hunting. I had shot a pigeon with a BB gun at age twelve, from the second-story window of my friend's brownstone in the Bronx, an experience that continues to plague me with guilt.

Chris was standing outside, surrounded by a cabal of other writers, all dressed in their tackle-shop flannels and worn leather boots, their plumes of cigarette smoke gathering in the glow of the bar's single neon.

"You're a poet, right?" Chris said.

"I'm on the fiction side, actually."

"Really?" he asked.

Was there something about the way I was dressed that made the fact that I was a fiction writer so unconvincing?

The other writers ashed their cigarettes and looked at their feet.

"Well," Chris said, tossing his cigarette, "good to meet you, man." He went back into the bar, and I went home.

Our next meeting was in a seminar taught by Charles D'Ambrosio. Chris had come as a guest speaker on the subject of fiction versus nonfiction. The nonfiction piece of his we were assigned was "Porn Bought My Football." I had not read it.

He was sitting in front of the class, legs crossed, some old cowboy boots kicking out of his jeans. A first-year, very-male-writer-in-the-making prompted Chris with a question-something long-winded and unfocused about southern writers.

"Hey, man," Chris interrupted. "You got a question in there?"

"Um. Well. Yes. Uh."

"If you're asking whether I identify myself as a southern writer, the quick answer is no. We could have lived anywhere. My father would still have been a pornographer."

A pornographer? I scanned the photocopied essay in front of me. 
Another question: "Was your mother also involved in writing pornography?"

Another: "Were your parents swingers?"

I couldn't tear through the pages fast enough.

Needless to say, I left that class and read the essay we had been assigned. I was enthralled, shocked. And it wasn't just the subject matter, but the artless and brilliant way in which he was able to tell this bizarre story.

This striking introduction led me to explore more of Chris's work. He is the author of five books: Kentucky Straight, Out of the Woods, The Same River Twice, No Heroes, and The Good Brother. His work has received fellowships from the Guggenheim Foundation, the Whiting Foundation, the Lannan Foundation, the NEA, and the Whiting Foundation. He received an award from the American Academy of Arts and Letters for "prose that takes risks." In 1996, he was selected by Granta as one of its "Top Twenty Young American Writers." His work is included in numerous anthologies, including Best American Short Stories, Best of the South, and Classic American Memoirs. He has written two television pilots as well as scripts for True Blood, Weeds, and Treme. He lives in Oxford, Mississippi.

I interviewed Chris in Iowa City in the spring of 2010.

Alex Dezen: What are you working on now?

Chris Offutt: A novel set in contemporary Lexington, which I recently finished. It's sort of a new genre-the "slow thriller." The protagonist is heavily armed and a very careful thinker. I've published several sections of it. Right now I've set it aside so I can be objective for a final revision.

Also, I've been working on a collection of stories for about twenty-two years. They're about a woman from Kentucky named Lucy. My idea was that I'd cover her life from ages eight to seventy-eight. I had the first two or three stories, and I had the end story. I really liked the end story where she goes off into the woods and dies by herself. At a certain point, I realized I had gaps. There was no story from ages forty to sixty. I had to come up with a story about a forty-five-year-old woman that picked up ten years after the last story, and I didn't like it. I wrote them, and they felt forced. I didn't think they were very good stories. But I was enamored by the external structure for a collection. 
The other thing I realized was that I'd been writing for thirty years and had not written much about sex. I'd written about men and women and relationships and all, but I'd really avoided writing about sex somehow. For a long time, that was another short story project.

AD: Did you feel there was a social pressure to avoid sex?

CO: It was probably because my father was a pornographer. He wrote pornography. Maybe that was why. Also, if you write about sex, there's only so many ways to do it. There's the language of the street or of the porn novel. Then there's medical language, very formal. Penis and vulva. I was trying to write some stories that dealt with sex and sexuality and also have humor in them. So I've had these two manuscripts I've been working on for a long time: the Lucy stories and the sex stories, plus the novel.

AD: Will the Lucy stories be your next publication?

CO: What I'm doing now is choosing the best stories from each manuscript 119 and bringing them together in one book. But publishing is in a shambles right now. And all the Hollywood shit has interfered with trying to make art.

AD: I think I understand that. I'm working on a novel and a collection of stories but also recording music, which has been my livelihood for the last ten years. Making music is incredibly distracting, so it's often a debilitating uphill battle.

CO: Writing is an uphill battle, and it's impossible to recognize progress because the progress occurs without you being aware of it, and the only way for you to be aware of it is to do it and then look back. It's not like math, where you learn to add, then you learn to subtract, then you move on to long division and geometry. With writing, it always feels as if I don't have much skill to begin with, I've lost what little I had, and everything sucks [laughs]. I think it's the writer's lot.

AD: Charles D'Ambrosio once told me in workshop that if the sentences aren't working, write shitty. I don't think I'm brave enough for that. 
CO: I think Charlie's advice is great. You can't adequately gauge the quality of the work when you're writing it. It's always shitty when you're first putting it down. It's supposed to be shitty. You have to have something to improve upon. So, if it feels shitty in the first place, why not embrace it? What I do is just burn through things in order to get something to revise.

AD: Do you think there isn't enough emphasis on revision in the workshop environment?

CO: I don't know. I can't speak for workshops or other teachers' approaches. In class, I always talked about revision. It's the most important element to writing. It actually means to re-see. Revision can be discussed in practical terms. As a teacher, I can only recommend techniques that have worked for me-or didn't work. The main thing is to find out for yourself.

AD: What are some of the things you teach your students about revision?

CO: The first one is to write about what you care about. Write about something that hurt you. Write about something that you're scared of. If you choose a subject with those three attributes, regardless of the quality of the first draft, you will have an emotional involvement in it. That's the first part. The next one is to really step away from the manuscript. It's hard for young writers-and for me-to realize you have a lifetime ahead of you. This thing's not going to be perfect in two weeks or two months. I step away from manuscripts for several months, sometimes years.

To revise adequately, you have to be objective, and therein lies the tricky part: if you generate a first draft that you have an emotional relationship with and that you've staked your identity on, you're heavily invested in that. Well, that means it's subjective. You put everything in. You cut your veins and bled on the page. It's impossible to be objective very soon after.

I believe that if you both embrace and surrender to the writing process, something's going to happen there on the page that's very separate from what you anticipated and what you thought you were doing-separate from what you had set out to do, and even separate from what you wanted to be doing. If you give it some time, you can look at the work and learn what it really is. That's when you cut everything out that doesn't support it. That may be huge chunks and huge scenes. It could be the first twenty pages, 
because on page twenty-one, this thing took off. No one in their right mind is going to cut the first twenty pages of a manuscript within the first few days of writing it.

On a smaller scale, what I tend to do with my own work is cut the first few pages and cut the last few pages. In the first few pages, there's that terrible self-consciousness, the blank page, trying to write something on it, knowing you're setting out to write a short story, wondering if your idea is sufficient enough. Will it be as good as any other story I've written? Eventually, that fades and the story begins. The same thing happens when you approach the ending. When you know the story is approaching the ending, that selfconsciousness kicks in again. And there's a reluctance to leave that imaginary world. It starts out difficult to access, then it's a fucking pleasure to inhabit, and then you have to leave these people and this world alone. For me, there's a tendency to prolong it a little bit and stay with them. And then there's also the self-consciousness about ending a story. Endings are important, and they're difficult. There's this tendency to write this big, glittering, wonderful ending that reads like someone tacked on this big ending to a short story. It hangs there like a chandelier in a shack.

AD: Then what's a good ending to a short story?

CO: To me, a story has three endings. There's the ending for the protagonist, his or her emotional ending. There's the ending to the events of the story. Then there's the structural ending to the story itself. It's hard to try to fit those in. I think ending with an image is always a strong idea. An image that's related to the protagonist.

AD: Related in an emotional way?

CO: In an emotional way, in a narrative way, and in a very personal way. Sometimes you hear this business about how an ending must reverberate back through the story, and I disagree. Or an ending must be something that's inevitable but also unpredictable. But if you think that way, then you're just sitting around driving yourself nuts trying to figure out if it's predictable. Well, how the hell would you know? You wrote the goddamn thing. So I don't worry about all that. What's important is the character, the 
person, and that person's ending. Then you can consider the formal and structural aspects.

AD: Frank Conroy was a mentor to you when you were a student at the Workshop, and the two of you became close friends after you graduated. Is that kind of one-on-one relationship important to your writing?

CO: It was particularly important to me, given my family background. I was always vulnerable to an older man who treated me well and with respect, since my father didn't.

AD: Do you still follow the one-minute-a-day rule? That you only have to write for one minute a day? You talked about that when you visited my class.

CO: Yeah. It works. It's easy to accomplish. It's a simple goal, and you almost always make it. I always make it. Then I double it, and then I quadruple it. I used to have time periods, pages, daily word count quotas. Although if I use the phrase "count quota," there's some part of my brain that will start using a lot of little words so I hit my word count sooner. Or if I have, say, a six-pages-a-day goal. Well, the more dialogue you write, the faster you accomplish those six pages. Those things were self-defeating. The minutea-day rule came from having a lot of other elements in my life that were conflicting, like kids and jobs and appointments-all that kind of stuff. If I had to be somewhere at ten thirty, it seemed like why start writing at nine thirty? By the time I get into it, I'm going to have to stop and change clothes and drive somewhere. So I just wouldn't do it. But if you only have to work one minute a day, there's always enough time.

AD: I have often used it myself, and it works. I find that when I have to write for a minute a day, I'll wind up writing more that day than I did the day before, when I said that I was going to write for four hours.

$\mathrm{CO}$ : Yeah. It creates a pressure. Writing for me is just this giant pressure, and if you say to yourself, I'm going to write for four hours a day-that's a huge pressure hanging over you. You check the clock constantly. "It's only been an hour! I have three more hours to go. I hate myself! I hate this writing!" It's a 
form of self-torture, and writing is hard enough. But working for a minute? I'm confident I can accomplish that goal.

AD: How do you feel about your first published book now, almost twenty years later?

CO: Kentucky Straight? I'm proud of it. Half of those stories I wrote in the Workshop, and they were roundly castigated by my fellow students. I still have their comments.

AD: How long have you been holding on to those?

CO: About twenty-three years.

AD: I've noticed that you're something of a collector. I've seen your collection of rocks-

CO: Yes. All with a hole in them, a natural perforation.

AD: Why do you collect things?

CO: I've got a collecting bug. When I was a kid, I collected rocks, feathers. I collected cool pieces of broken glass, bird nests, bark, and leaves. There's an obsessive element in it, which I think is part of my makeup in terms of being a writer. I still collect those things. I collect wheat pennies. And now books, I suppose. And some taxidermy.

AD: Like possums.

CO: Yeah, I want to be the Noah of taxidermy. Every species.

AD: How do you think that obsessive personality manifests in your writing?

CO: I can get very obsessed with writing, and I think it benefits the writing. If I'm captured by what I'm working on, I can work six hours a day. I can work ten hours a day. And I can work seven days a week. When that happens, I tend to lose weight. I sleep less, eat less. There's a euphoria that's possible 
from that, a euphoria that doesn't occur with collecting rocks, but it's the same kind of obsessive focus.

AD: Do you feel like this obsessive collecting helps temper the need for the euphoria that writing brings when you're not able to write?

CO: The act of writing is such an intense enterprise. It takes all my focus. All my mind. All my energy. All my emotions. It's exhausting. And when it's done, then what? Well, I've had this daily habit of getting up and focusing exclusively on one activity. So what do I do when I finish a draft? I can't just stop and start another story the next day. I wish I could.

AD: Is it depressing when you finish a story?

CO: No, more of a restless exhaustion. That's where these pseudo-hobbies, like rock collecting or reading about art history, Zen, the CIA, or quantum mechanics can kick in. When the cistern of writing is depleted, it has to fill with rainwater, so I have to do something. I can apply that same sort of focus to something else, but it's not so draining because reading about a thing is not doing the thing. There's no invention on my part. Some people use household projects, but I don't. Other writers will turn to drugs and alcohol, sex and gambling. Those things fill up the same void, and you can do them with the same focus and intensity, but, you know, it could be the end of you. Especially if you combine all four [laughs].

AD: Do you want to talk about your Hollywood work?

CO: Not really. But I will a little. I wrote ten screenplays in four years, and began working as a producer. Four scripts got shot for TV, and we shot a short film in Iowa that I wrote. I like short films a lot.

AD: Did you find it easy to maneuver your way around a Hollywood writers' room? What was that like, making that transition?

CO: There was one guy who told me that I hadn't paid my dues to have a job in Hollywood. And I said, "Look, I've paid another kind of dues. I spent twenty-five years alone in a room, writing." He said, "I've spent the last 
fifteen years in writers' rooms, making friends." That was when I realized I wouldn't fit in very well in this world.

\section{AD: You wrote for True Blood.}

CO: Yeah, season one. It was difficult. First there was the writers' strike. Then I was lonely in L.A. and got a little depressed. Plus, I didn't have a car for the first four months because I was scared to drive out there. When we went into production, I had to get a car to drive those crazy freeways to the location. Then I worked ten to fourteen hours straight, about half of them at night, because it was a vampire show. I did it for the money, and it paid for my sons' college tuitions. And that was about as satisfying as it gets out there. Strictly financial reward. I decided to get out.

AD: How many years did it take you to write your first book, Kentucky Straight?

CO: One of those stories I wrote in Kentucky, in the winter, in a cabin with no bathroom and no heat-just a wood stove and a couch-bed. I wrote it to use as my application for the Workshop. That was "Horseweed." Because I'd written it to get in, I used that story for my first workshop. It was raked over the coals, but I got a lot out of it. Some people made some pretty good points about the temporal movement, which I had to go home and research to see what the hell they were talking about. Turns out it was fancy talk for "time." Four years later, I had a book. I wrote four of those stories in the Workshop and four of them two years after, when I got out. And that was Kentucky Straight.

AD: So we're talking about four years from inception to publication?

CO: Yeah. But twenty years of preparation.

AD: The book you're working on now has taken you twenty years. Why do you think that is? Are you simply more careful? Are you just too busy with other things in life? 
CO: When you first start out, a writer has a lot more energy in general. You have a lot to prove and absolutely nothing to lose. Those are great freedoms. But yes, I've been busy. I've had children. I'm very active in their lives. I've been home with them throughout their lives, which is both a pleasure and a drawback in terms of writing.

Don't misunderstand this idea that l've spent twenty-two years trying to write a book of short stories. I've published all the stories. Some in different forms, under different titles, with different protagonists. It's just a case of making sure that a collection was exactly what I wanted. That's important. I'm not ashamed of what I've written or ashamed of anything I've published. I know some writers who feel that way. I also wrote two books that I've never even sent out. Plus another two books that I sent to editors, then changed my mind and withdrew them from publication.

AD: Why did you withdraw them?

CO: I wasn't satisfied with them. I knew they weren't good enough. They were adequate. I didn't want to consciously put into the world something that I knew was merely adequate.

AD: Do you think you might be holding yourself to too high a standard?

CO: I've probably always held myself to a standard too high to achieve. I think I did it with all the books that I've published. I think I do it in every element of my life.

AD: Do you think that's helpful?

CO: I think it does help me and my writing. It translates to pressure and responsibility, and it makes me work harder. I believe in it. I also think it makes it difficult for people to be around me at times [laughs].

I'm sure someone could say, Chris, you're out of your mind. Maybe I am. But at the same time, I'm satisfied with everything that I've published. I made it as good as I could make it at that time. I think it would be a terrible thing, as a writer, to look at something after the fact and say, damn, why did I do that? What would it have hurt if I'd held onto that for a year or two to make it better? What would I have lost? The house? The car? Nothing like 
that. Only my own self-respect. I wish everything I wrote was as good as I wanted it to be. But it takes a little effort.

All a writer has is time and his mind. So I try to use the time well, with an eye on the eventual body of work. I'm on the planet to serve literature. I try to write for immortality, I suppose. 